\title{
СОЦИАЛЬНО-ПСИХОЛОГИЧЕСКИЕ ФАКТОРЫ ЭФФЕКТИВНОСТИ СЛУЖЕБНОЙ ДЕЯТЕЛЬНОСТИ ЖЕНЩИН-СОТРУДНИКОВ ОРГАНОВ ВНУТРЕННИХ ДЕЛ
}

\author{
Кузнецова Ольга Владимировна
}

В статье представлены результаты эмпирического исследования, челью которого было выявить сочиально-психологические факторы эффективности служебной деятельности женщин-сотрудников. Актуальность исследования поддерживалась устойчивой тенденцией увеличения количества женщин на службе в ОВД в настоящее время и приоритетностью для женщин социально-психологических условий в профессиональной деятельности. Понимая под социально-психологическими факторами связи, феномены и закономерности внутренней социально-психологической сферы правоохранительной деятельности группового (служебный коллектив) и индивидуального (социально-психологические особенности личности) уровней, были изучены социально-психологический климат в служебных коллективах, сочиометрический статус, уровень сформированности правосознания и личностные особенности женщин-сотрудников ОВД во взаимосвязи с эффективностью их служебной деятельности.

Оченка эффективности служебной деятельности проводилась с помощью методики экспертных оценок, социально-психологические исследования в служебных коллективах - с помощью модифицированной социометрической методики М. И. Марьина; для индивидуальной психологической диагностики использовались методики: стандартизированный многофакторный метод исследования личности СМИЛЛ. Н. Собчик, методика изучения правосознания Л. А. Ясюковой. По результатам была установлена взаимосвязь эффективности служебной деятельности женщин-сотрудников с социально-психологическими показателями служебных коллективов органов внутренних дел, которые обусловлены количественным и гендерным составом; с сочиометрическими показателями их деловых и эмочиональных статусов, которые опосредованы личностными особенностями женщин-сотрудников и особенностями самого коллектива. Выявлено, что основная часть женщин-сотрудников ОВД профессионально компетентны, эмоционально привлекательны, общительны и пользуются авторитетом в своих коллективах. Уровень сформированности индивидуального правосознания положительно связан с эффективностью служебной деятельности женшин-сотрудников ОВД. Для женшин-сотрудников ОВД характерен стенический тип реагирования, преобладание возбудимых черт 
личности. Такие личностные особенности, как мягкость, сентиментальность, женственность, чувствительность, стремление быть опекаемой, найти опору, снижают эффективность служебной деятельности женщин-сотрудников.

Полученные данные позволили выработать практические рекомендачии по сочиально-психологическому сопровождению служебной деятельности женщин-сотрудников органов внутренних дел.

Ключевые слова: сочиально-психологические факторы, женшины-сотрудники, служебная деятельность, эффективность деятельности, социально-психологический климат, социометрический статус, правосознание, личностные особенности.

\section{Введение}

Социально-ролевые изменения, которые происходят в современном обществе, затрагивают многие сферы жизнедеятельности человека. В настоящее время женщины осваивают новые для себя профессии и виды деятельности, стремятся к выполнению более широких функций, чем традиционные домашние и семейные обязанности. Данные тенденции привели к активному участию женщин не только в общественной и государственной жизни, но и к службе в Вооруженных Силах и органах внутренних дел.

По статистическим данным службу в ОВД сейчас проходят около 200 тысяч женщин, что составляет более 20 \% от общей численности личного состава, и наблюдается устойчивая тенденция увеличения этой доли среди сотрудников. Женщины служат почти во всех подразделениях органов внутренних дел: по предупреждению правонарушений среди несовершеннолетних - 79,0\% составляют женщины-сотрудники; по организации дознания - 73,0 \%; следствия - 58,9\%; в кадровой - 54,0 \% и экспертно-криминалистической - 35,7 \% службах; вневедомственной охране - 11,4 \%; уголовном розыске - 8,7 \%; ГИБДД - 9,5 \%; в патрульно-постовой службе - 9,6 \% [17].

С социально-психологической точки зрения увеличение количества женщин на службе в ОВД сопровождается изменениями в гендерном составе служебных коллективов, усложнением взаимоотношений между женщинамисотрудниками и мужчинами-сотрудниками и появлением нового типа проблем. Так, проведенные исследования в воинских коллективах показали, что большинство военнослужащих представляют женщин как играющих менее значимую профессиональную роль и выполняющих функцию, связанную с заботой и оказанием помощи мужчинам (В. В. Овчинникова, 2006) [12]; у женщин на военной службе в той или иной степени возникают напряженные отношения с мужчинами-руководителями, потенциально конфликтные ситуации создает их назначение на мужские вакансии (А. И. Смирнов, 2000) [19]; командиры (начальники) слабо знают и учитывают их индивидуально-психологические 
особенности (Д. Ю. Ануфриева, 2009; М. А. Демина, 2005) [2, 4]; офицерыруководители, которые имеют в подчинении женщин, утверждают, что испытывают систематические трудности при профессиональном воспитании военнослужащих-женщин; признают необходимость совершенствования уровня своей гендерной культуры (М. А. Демина, 2005) [4]. Исследование в коллективах органов внутренних дел выявило, что женщины-сотрудники не реализуют в полной мере свой личностный и профессиональный потенциал в соответствии с полученным образованием, сталкиваются с ограничением возможностей профессиональной переподготовки и получения высшего ведомственного образования, и в связи с этим не видят для себя перспектив в профессиональной карьере (Д. Ю. Ануфриева, 2009) [2].

Приведенные научные исследования, безусловно, освещают отдельные проблемы службы женщин в ОВД, но в современных научных трудах не поднимаются вопросы социально-психологического сопровождения служебной деятельности женщин-сотрудников, социально-психологических факторов эффективности их профессиональной деятельности.

Актуальность исследования поддерживается еще и особенностями самих женщин. Так, анализ литературных источников показал, что многие авторы отмечают приоритетность для женщин в их профессиональной деятельности социально-психологических условий, наличие благоприятных взаимоотношений в коллективах, оценок их труда (Е. И. Комаров и В. Ф. Жукова, Э. Мэйо, Н. Н. Обозов, Э. Ранник) [7, 11, 26]. Также авторы Т. В. Бендас, Е. П. Ильин, Е. И. Комаров и В. Ф. Жукова, Э. Мэйо, Н. Н. Обозов $[3,6,7,11,26]$ приходят к выводу, что учитывание гендерных особенностей при организации работы обеспечивает успешность деятельности и мужчин и женщин.

Исходя из всего вышеизложенного, цель нашего исследования была определена как выявление социально-психологических факторов эффективности служебной деятельности женщин-сотрудников в интересах совершенствования организации работы с личным составом с учетом гендерного состава служб и подразделений органов внутренних дел.

Общая выборка состояла из служебных коллективов органов внутренних дел и женщин-сотрудников, проходящих службу в данных коллективах. Социально-психологические исследования проведены в 107 служебных коллективах органов внутренних дел. Всего в ходе социально-психологических исследований учтено мнение 2021 сотрудника, в ходе индивидуальной психологической диагностики обследовано 367 женщин-сотрудников.

\section{Методы}

Методы исследования включали: теоретический анализ, метод экспертных оценок, анкетирование, социометрию, психодиагностическое обследование 
и методы математической статистики. Социально-психологические исследования в служебных коллективах проводились с помощью модифицированной социометрической методики (М. И. Марьин), зарегистрированной в РОСПАТЕНТ (Свидетельство о государственной регистрации программы для ЭВМ № 2013613249). Для индивидуальной психологической диагностики использовались методики: стандартизированный многофакторный метод исследования личности СМИЛ Л. Н. Собчик [20], методика изучения правосознания Л. А. Ясюковой [24].

В настоящее время в системе МВД отсутствует единый подход в оценке эффективности служебной деятельности сотрудников ОВД, который бы регламентировался определенным нормативным актом. Отсутствуют критерии, условия, категории оценок. Само понятие эффективности служебной деятельности в ОВД не имеет единой формулировки.

Авторы М. И. Марьин, И. О. Котенев, Л. Е. Киселева (Академия управления МВД России) в своей работе подробно рассматривают теоретические и методические подходы к оценке эффективности деятельности, понимая под эффективностью интегральную характеристику профессиональной деятельности, качество труда, включающее в себя и технико-экономические, и социальные, и психофизиологические аспекты человеческой деятельности $[10$, с. 5]. Описывая множество подходов к оценке профессиональной деятельности, авторы рассматривают метод экспертных оценок как наиболее подходящий для системы органов внутренних дел в настоящее время.

В литературе, посвященной изучению профессиональной деятельности сотрудников ОВД, авторы Б. Г. Бовин, Н. И. Мягких, А. Д. Сафронов, ссылаясь на социономический характер профессии, также описывают метод экспертных оценок как наиболее адекватный для оценки эффективности служебной деятельности сотрудника ОВД [13].

Основываясь на вышеперечисленных исследованиях, для получения внешнего критерия оценки служебной деятельности была использована экспертная методика «Основные профессионально важные качества и уровни их градации для целей экспертной оценки» [15], с помощью которой были изучены профессионально важные качества и эффективность служебной деятельности женщин-сотрудников. Для эффективного использования полученных данных была применена формула математической статистики по Е. Сидоренко [18], с помощью которой разделение всей выборки на группы с низкой, средней и высокой эффективностью служебной деятельности производится по критерию отклонения значений от средней величины на $1 / 2$ стандартного отклонения.

Таким образом, все женщины-сотрудники были распределены по трем группам: первая группа - с показателями высокой эффективности служебной 
деятельности (111 человек - 30 \%), вторая группа - с показателями средней эффективности (156 человек - 42,5\%), третья группа - с показателями низкой эффективности (100 человек - 27,5%). Исключение второй группы позволило получить две полярные группы: с высокой и низкой эффективностью служебной деятельности.

\section{Обсуждение результатов}

В ходе проводимого эмпирического исследования был изучен социальнопсихологический климат в служебных коллективах и такие его показатели, как сплоченность, напряженность, удовлетворенность, конфликтность, взаимность и экспансия. Установлено, что в 21,5% коллективов органов внутренних дел социально-психологический климат благоприятный. В это число вошли коллективы небольшие (среднее количество сотрудников $13+9$ ), по своему составу и однородные мужские $(61,9 \%)$, и смешанные - женщины и мужчины (38,1 \%). Служебные коллективы с неустойчивым социально-психологическим климатом составляют 78,5%. В их число вошли коллективы большие по численности (среднее количество сотрудников $20+11)$ и смешанные по составу (76,3 \%). Служебных коллективов с неблагоприятным социальнопсихологическим климатом в настоящем исследовании не выявлено.

В литературе имеются научные труды, посвященные изучению социально-психологических процессов и явлений в служебных коллективах ОВД. Вопросам социально-психологического климата уделено внимание в работах М. И. Марьина, И. В. Иванихиной, С. И. Ловчан, А. И. Папкина, А. М. Столяренко, В. И. Черненилова, И. В. Якушева [9, 14, 16, 22, 23]; психологической сплоченности - в работах М. И. Марьина, Е. В. Бобринева, Е. Ю. Сушкиной [22]; методике социально-психологических исследований - в работах М. И. Марьина, И. А. Андреевой и В. А. Корчмарюк $[1,10]$.

Авторы указывают, что «работа органов внутренних дел в обеспечении законности и правопорядка является разновидностью индивидуальногрупповой деятельности, эффективность и надежность которой во многом зависит от социально-психологических явлений в подразделении» [1, с. 3].

В отличие от коллективов гражданских организаций коллектив органов внутренних дел имеет свою специфику, которая выражается в следующих характеристиках: руководители и сотрудники обязаны соблюдать субординацию, уставные отношения, служебную дисциплину; в приказах, распоряжениях, инструкциях, положениях и других нормативных правовых актах МВД России регламентируются права и обязанности должностных лиц, в том числе и социально-психологические отношения; правоохранительная деятельность относится к видам общественно необходимого труда, связанного с экстремальными условиями и элементами риска для жизни [22]. 
В настоящем исследовании мы изучаем социально-психологический климат в коллективах с точки зрения его взаимосвязи с эффективностью служебной деятельности отдельной категории сотрудников ОВД, которая стала актуальна для системы МВД в настоящее время, т. е. женщин-сотрудников.

Статистический анализ полученных в нашем исследовании результатов свидетельствует о том, что состояние социально-психологического климата на достоверном уровне коррелирует с количественным $(r=0,265 ; p<0,05)$ и гендерным составом служебного коллектива $(r=0,496 ; p<0,05)$.

Статистически значимые различия в составе коллективов с благоприятным и неустойчивым социально-психологическим климатом получены в случаях, когда женщин нет в коллективе - коллектив однородный мужской $\left(\varphi_{\text {эмп }}-3,140, p<0,01\right)$ и когда доля женщин в коллективе свыше $20 \%\left(\varphi_{\text {эмп }}-1,661, p<0,05\right)$. Количество женщин в коллективе от 0 \% до $20 \%$ не значимо для социально-психологического климата, т. е. не оказывает влияния на общий климат в коллективе (таблица 1).

Таблица 1.

Зависимость состояния социально-психологического климата от доли женщин-сотрудников в служебных коллективах ОВД

\begin{tabular}{|c|c|c|c|c|c|}
\hline \multicolumn{2}{|c|}{$\begin{array}{c}\text { Доля женщин в } \\
\text { коллективе }\end{array}$} & $0 \%$ & $\begin{array}{c}\text { Om } 1 \% \text { do } \\
20 \%\end{array}$ & $\begin{array}{c}\text { Om } 21 \% \text { do } \\
49 \%\end{array}$ & $\begin{array}{l}50 \% \text { u } \\
\text { выue }\end{array}$ \\
\hline \multirow{2}{*}{$\begin{array}{l}\text { Количество } \\
\text { коллективов }\end{array}$} & $\begin{array}{l}\text { С благопри- } \\
\text { ятным СПК }\end{array}$ & $56,5 \%$ & $26,1 \%$ & $4,3 \%$ & $13,0 \%$ \\
\hline & $\begin{array}{c}\text { С неустойчи } \\
\text { вым СПК }\end{array}$ & $21,4 \%$ & $34,5 \%$ & $15,5 \%$ & $28,6 \%$ \\
\hline \multicolumn{2}{|c|}{$\varphi_{\text {วMn }}$} & 3,140 & 0,782 & 1,661 & 1,661 \\
\hline \multicolumn{2}{|c|}{$p<$} & 0,01 & - & 0,05 & 0,05 \\
\hline
\end{tabular}

Данные результаты позволяют сделать вывод, что смешанный гендерный состав коллектива с долей женщин до 20 \% существенно не влияет на социально-психологический климат. Но при увеличении количества женщин-сотрудников в служебных коллективах органов внутренних дел свыше 20 \% в социально-психологическом климате возможны изменения в сторону неустойчивости.

Существующие взаимосвязи состояния социально-психологического климата с количественным и качественным составом коллектива позволяют сделать вывод, что большие по количеству и смешанные по гендерному составу коллективы требуют от руководителя проявления особой гибкости, высокой компетентности и умения использовать социально-психологические методы в управлении. Особого искусства управления от руководителя требуют служебные коллективы ОВД с долей женщин-сотрудников свыше 20 \%. 
Для выбора оптимального стиля управления руководителю необходимо учитывать социально-психологические характеристики коллективов, которые раскрываются с помощью постоянного мониторинга. А также учитывание выявленных взаимосвязей при комплектовании служебных коллективов ОВД поможет руководителю с первых шагов влиять на формирование благоприятного социально-психологического климата и корректировать свой стиль управления в зависимости от состава коллектива.

Дальнейший анализ выявил наличие взаимосвязи между состоянием социально-психологического климата и эффективностью служебной деятельности женщин-сотрудников (таблица 2).

Таблица 2.

Распределение женщин-сотрудников с высокой и низкой эффективностью служебной деятельности в коллективах ОВД

\begin{tabular}{|c|c|c|}
\hline \multirow{2}{*}{ Состояние СПК } & \multicolumn{2}{|c|}{ Женщины-сотрудники, \% } \\
\cline { 2 - 3 } & $\begin{array}{c}\text { с высокой } \\
\text { эффективностью }\end{array}$ & $\begin{array}{c}\text { с низкой } \\
\text { эффективностью }\end{array}$ \\
\hline Благоприятный СПК & 61,1 & 5,6 \\
\hline Неустойчивый СПК & 29,6 & 27,6 \\
\hline$\varphi_{\text {эмп }}$ & 2,576 & 2,519 \\
\hline$p<$ & 0,01 & 0,01 \\
\hline
\end{tabular}

Данные показали, что женщин-сотрудников с высокой эффективностью служебной деятельности в служебных коллективах с благоприятным социально-психологическим климатом на достоверном уровне больше, чем в коллективах с неустойчивым социально-психологическим климатом $\left(\varphi_{\text {эмп }}-2,576 ; p<0,01\right)$. Женщин-сотрудников с низкой эффективностью служебной деятельности на достоверном уровне меньше в благоприятных коллективах, чем в коллективах с неустойчивым социально-психологическим климатом $\left(\varphi_{\text {эмп }}-2,519 ; \mathrm{p}<0,01\right)$.

Результаты корреляционного анализа подтвердили взаимосвязь социально-психологических показателей с эффективностью служебной деятельности женщин-сотрудников: эффективность служебной деятельности женщин-сотрудников коррелирует на уровне статистической значимости со сплоченностью коллектива $(r=0,29 ; p<0,05)$, напряженностью $(r=-0,27 ; p<0,05)$, конфликтностью в коллективе $(r=-0,27 ; p<0,05)$ и экспансией между минигруппами в коллективе $(r=-0,3 ; p<0,05)$.

В соответствии с задачами исследования были определены индивидуальные социометрические статусы женщин-сотрудников в служебных коллективах (деловой, эмоциональный, интегральный и управленческий). 
Большинство женщин-сотрудников имеют средний уровень делового статуса $(62,9 \%)$ и высокий (10,9 \%). Это характеризует женщин-сотрудников как деловых лидеров в своих коллективах, имеющих высокую профессиональную компетентность и высокий уровень авторитета в коллективе. Всего 73,8 \% женщин-сотрудников в деловом плане оцениваются своими коллегами позитивно, как профессионально подготовленные сотрудники, пользующиеся авторитетом. Большинство женщин-сотрудников имеют средний уровень эмоционального статуса (81,3 \%) и высокий уровень (6,6 \%). Это может характеризовать женщин-сотрудников как эмоциональных лидеров в своих коллективах, имеющих высокую эмоциональную привлекательность, высокую общительность. Всего 87,9 \% женщин-сотрудников в эмоциональном плане оцениваются своими коллегами как общительные, эмоционально привлекательные и хорошо принимаются коллегами в своих коллективах. При ответе на вопрос «Выбрали бы Вы этого сотрудника на место непосредственного начальника?» у женщин-сотрудников преобладают низкие оценки - 62,8 \%. Высокий и средний уровни управленческого статуса имеют $37,2 \%$ женщин-сотрудников.

Анализ деловых, эмоциональных и управленческих статусов женщин-сотрудников выявил противоречивость оценок. При преобладании высоких и средних оценок деловых и эмоциональных качеств женщин-сотрудников у управленческого статуса преобладают низкие оценки. То есть, признавая достаточную профессиональную и коммуникативную компетентность, эмоциональную привлекательность женщин-сотрудников, коллеги не стремятся выдвигать их на руководящие должности. Можно предположить, что в основе таких оценок лежит стереотип, что руководителем должен быть только мужчина (особенно в силовых структурах). Поэтому коллеги не стремятся выбирать женщин на должность начальника. Это отчасти совпадает с результатами исследований, проведенных Т. А. Ивановой (2000) [5]. В ее работе руководителям структурных подразделений органов внутренних дел было предложено выбрать одного из двух претендентов (мужчина и женщина) на вакантную должность с равноценной профессиональной подготовкой и одинаковым стажем работы. В итоге 87,4 \% руководителей в такой ситуации выбрали бы мужчину.

Корреляционный анализ обнаружил наличие положительной, статистически достоверной связи между деловыми ( $r=0,51$; $p<0,05)$, эмоциональными ( $r=0,43 ; p<0,05)$, интегральными ( $r=0,52 ; p<0,05)$, управленческими $(r=0,4 ; p<0,05)$ статусами женщин-сотрудников и эффективностью их служебной деятельности.

Анализ результатов социально-психологических исследований и изучения личностных особенностей женщин-сотрудников позволил выявить 
положительную, статистически достоверную связь между деловыми, эмоциональными и интегральными статусами женщин-сотрудников и 5-й шкалой СМИЛ «женственность - мужественность» (рисунок 1).

Шкала 5 «мужественности - женственности» характеризует полоролевой стиль поведения личности. Л. Н. Собчик указывает, что повышенные показатели по 5-й шкале означают отклонение от типичного для данного пола ролевого поведения и усложнение сексуальной межличностной адаптации [20]. У женщин повышение 5-й шкалы отражает черты независимости, самостоятельности, уверенности, решительности. И чем выше показатели данной шкалы, тем сильнее проявляются данные личностные особенности у женщин.

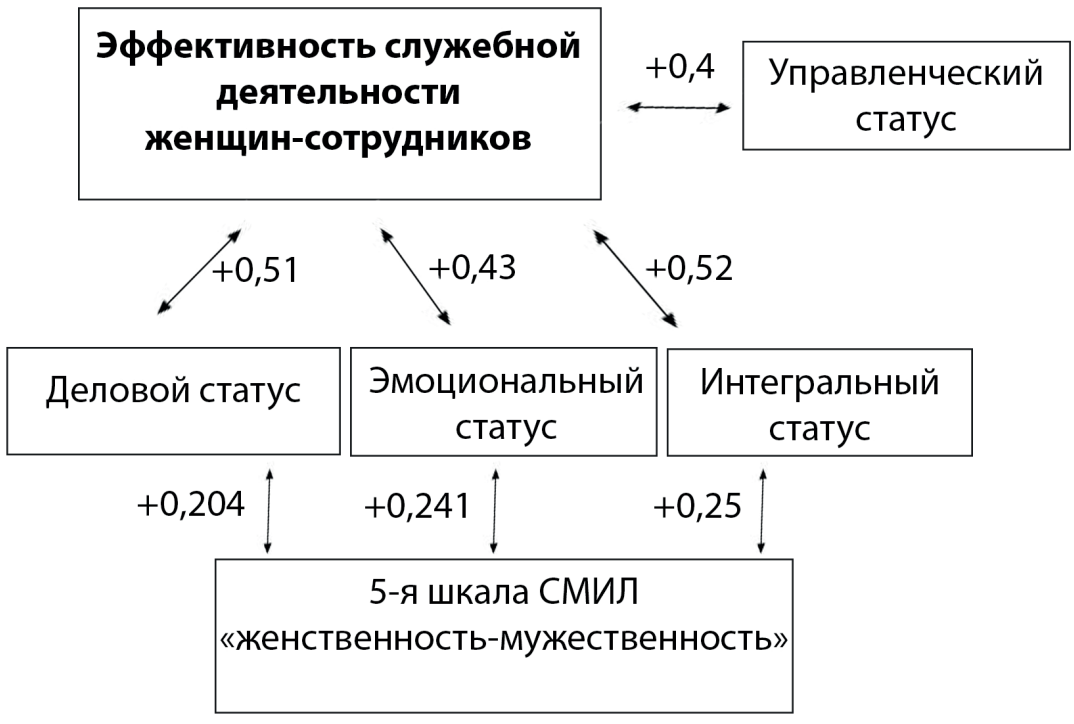

Рисунок 1. Взаимосвязь между личностными особенностями и социометрическими статусами женщин-сотрудников

Полученные взаимосвязи дали основание полагать, что в коллективах органов внутренних дел принимают и признают в большей степени женщин, которые проявляют в своем поведении такие черты, как самостоятельность, независимость, уверенность. Такие женщины в большей степени пользуются и профессиональным и личностным авторитетом у своих коллег. Но данные выводы не применимы к управленческому статусу женщин-сотрудников. Анализ 
не выявил статистически достоверных взаимосвязей между управленческим статусом и особенностями личности женщин-сотрудников. Это позволяет сделать вывод, что личностные особенности женщин-сотрудников не влияют на мнение коллег относительно выдвижения женщин на руководящие должности. Отдавая предпочтение самостоятельным, независимым, уверенным женщинам, оценивая их профессионально компетентными, эмоционально привлекательными и общительными, в роли потенциальных руководителей коллеги их не рассматривают.

Оценивая уровень сформированности правосознания (автор методики Л. А. Ясюкова указывает, что правосознание является частью обыденного сознания, его внутренняя структура может быть противоречива и может включать не только рациональные, но и эмоциональные компоненты; правосознание имеет в своей основе морально-нравственные установки, но не сводимо к ним и является специфическим образованием; выделяет три самостоятельные сферы функционирования правосознания: бытовую, деловую и гражданскую; также методикой замеряется уровень правовых знаний, - прим. автора), как важного социально-психологического качества сотрудника ОВД (А. М. Столяренко) [23], получили, что средние значения правосознания у женщин-сотрудников с низкой эффективностью находятся в рамках «противоречивого и неполноценного правосознания» (2-ой уровень). А средние значения правосознания женщин-сотрудников с высокой эффективностью находятся в рамках «в основном сформированного» правосознания (3-й уровень). Данный уровень является более высоким и характерен для личности, которая в своей деятельности старается не нарушать существующие законы и различные положения, достаточно надежна в деловой сфере, корректна в деловом взаимодействии [24].

Корреляционный анализ позволил установить статистически достоверную связь между эффективностью служебной деятельности и общим уровнем сформированности правосознания ( $r=0,34 ; p<0,05)$; показателем уровня сформированности правосознания в деловой сфере $(r=0,33 ; p<0,05)$ и бытовой сфере $(r=0,24 ; p<0,05)$. Деловая сфера в развитии правосознания характеризуется такими чертами личности, как обязательность в деловых вопросах, в совместной работе, склонность действовать в соответствии с установленными нормами. Бытовая сфера функционирования правосознания определяет область межличностных взаимодействий и описывает такие характеристики, как понимание морально-этических норм групповых взаимоотношений, понимание систем жизненных ценностей других людей.

Исходя из полученных данных, было определено, что в целом уровень сформированности правосознания, наличие установки на соблюдение правовых норм связаны с эффективностью служебной деятельности 
женщин-сотрудников. По данным Л. А. Ясюковой, при несформированности правосознания личность ориентируется на свои личные эмоциональные оценки, порой отрицая нормы и правила общества [25]. При такой эмоционально-оценочной ориентации у женщин-сотрудников выполнение поставленных правоохранительных задач может подменяться личными интересами, что несовместимо с профессиональной деятельностью сотрудника органов внутренних дел.

При изучении личностных особенностей женщин-сотрудников с помощью методики СМИЛ (Л. Н. Собчик) [20] были получены усредненные профили групп женщин-сотрудников с высокой и низкой эффективностью служебной деятельности (таблица 3). Полученные данные указывают, что в профилях женщин-сотрудников обеих групп ведущими являются шкалы 4 «импульсивность» и 9 «оптимистичность». Это позволило сделать вывод, что для женщин-сотрудников вне зависимости от эффективности их служебной деятельности характерен стенический тип реагирования, преобладание возбудимых черт. Такому типу личности присущи оптимистичность, высокая мотивация достижений, высокая потребность в самореализации, уверенность и быстрота в принятии решений.

Таблича 3.

Усредненные профили групп женщин-сотрудников с высокой и низкой эффективностью служебной деятельности

\begin{tabular}{|c|c|c|c|c|c|c|c|c|c|c|c|c|c|}
\hline Шкалы Смил & $\boldsymbol{L}$ & $\boldsymbol{F}$ & $\boldsymbol{K}$ & $\mathbf{1}$ & $\mathbf{2}$ & $\mathbf{3}$ & $\mathbf{4}$ & $\mathbf{5}$ & $\mathbf{6}$ & $\mathbf{7}$ & $\mathbf{8}$ & $\mathbf{9}$ & $\mathbf{0}$ \\
\hline $\begin{array}{c}\text { Группа с высо- } \\
\text { кой эффектив- } \\
\text { ностью }\end{array}$ & 48,2 & 55,2 & 62,4 & 50,2 & 48,5 & 49,3 & $\mathbf{5 6 , 2}$ & 50,3 & 48,1 & 51,1 & 53,5 & $\mathbf{5 8 , 1}$ & 49,2 \\
\hline $\begin{array}{c}\text { Группа с низ- } \\
\text { кой эффектив- } \\
\text { ностью }\end{array}$ & 49,6 & 55,3 & 63,3 & 51,1 & 47,8 & 50,5 & $\mathbf{5 4 , 6}$ & 50,6 & 45,9 & 51,3 & 54,2 & $\mathbf{6 0 , 1}$ & 47,2 \\
\hline
\end{tabular}

Условные обозначения: $L$ - ложь, $F$ - достоверность, $K$ - коррекция, 1 - «сверхконтроль», 2 - пессимистичность, 3 - эмоциональная лабильность, 4 - импульсивность , 5 - мужественность/женственность, 6 - ригидность, 7 - тревожность, 8 - индивидуальность, 9 - оптимистичность, 0 - интроверсия.

Анализ особенностей личности женщин-сотрудников показал, что для эффективности служебной деятельности значимы показатели 5-й шкалы (ниже 40 Т-баллов в профиле), которые отражают женственный стиль поведения: мягкость, сентиментальность, чувствительность, стремление быть опекаемой, найти опору (таблица 4). 


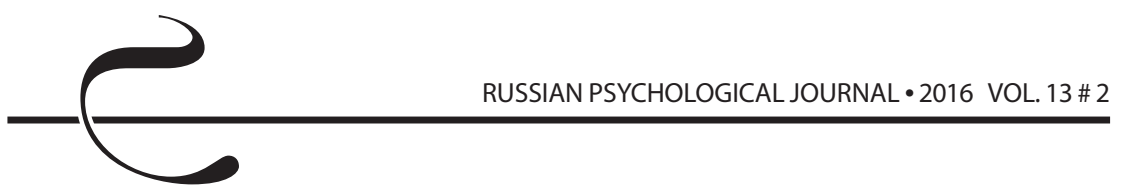

Таблица 4.

Взаимосвязь 5-й шкалы СМИЛ с эффективностью служебной деятельности женщин-сотрудников

\begin{tabular}{|c|c|c|c|}
\hline \multirow{2}{*}{$\begin{array}{c}\text { Женшины- } \\
\text { сотрудники ОВД }\end{array}$} & \multicolumn{3}{|c|}{ Значения 5 шкалы в т-баллах } \\
\cline { 2 - 4 } & ниже 40 & от $\mathbf{4 0}$ до 60 & выше 60 \\
\hline $\begin{array}{c}\text { Группа с высокой } \\
\text { эффективностью }\end{array}$ & $13,9 \%$ & $67,4 \%$ & $18,8 \%$ \\
\hline $\begin{array}{c}\text { Группа с низкой } \\
\text { эффективностью }\end{array}$ & $36,8 \%$ & $52,7 \%$ & $10,5 \%$ \\
\hline$\varphi_{\text {эмп }}$ & 2,412 & 1,361 & 1,042 \\
\hline$p<$ & 0,01 & - & - \\
\hline
\end{tabular}

Выявлены значимые различия в количестве женщин-сотрудников со сниженными значениями 5-й шкалы в группах с высокой и низкой эффективностью служебной деятельности $\left(\varphi_{\text {эмп }}=2,412, \mathrm{p}<0,01\right)$. Так, среди женщинсотрудников с низкой эффективностью служебной деятельности женщин с низкими значениями 5-й шкалы - 36,7 \%, а в группе с высокой эффективностью - 13,9 \%. У женщин-сотрудников с присутствием в личностных характеристиках мягкости и женственности в большей степени эффективность служебной деятельности оценивается как низкая.

А. М. Столяренко в своих трудах, описывая правоохранительную деятельность с точки зрения внешней и внутренней социально-психологической сфер, выделяет в каждой сфере группы социально-психологических связей, феноменов и зависимостей. Во внутренней социально-психологической сфере правоохранительной деятельности автор выделяет три группы факторов: психология большой профессиональной правоохранительной общности; психология коллектива правоохранительного органа; социально-психологические особенности личности сотрудников [21]. В связи с этим в настоящей работе факторы рассматривались как связи, феномены и закономерности внутренней социально-психологической сферы правоохранительной деятельности группового (служебный коллектив) и индивидуального (социальнопсихологические особенности личности) уровней.

С целью выделения социально-психологических факторов эффективности служебной деятельности женщин-сотрудников был проведен факторный анализ экспериментальных данных, полученных в результате исследования. Получено 10 главных факторов с собственными значениями больше 1,0. С высокими значениями коэффициента нагрузки показатель эффективности служебной деятельности вошел в три выделенных фактора. 
В первый фактор вошли такие социально-психологические показатели служебных коллективов, как сплоченность, напряженность, удовлетворенность и конфликтность, взаимность и экспансия. Это позволило нам назвать данный фактор «социально-психологические показатели служебных коллективов».

Во второй фактор вошли: общий балл правосознания, сформированность правосознания в деловой сфере, уровень правовых знаний и сформированность правосознания в гражданской сфере. Также в данный фактор вошли показатель возраста - 0,47 и показатель стажа службы в ОВД - 0,45. Это позволило говорить о том, что уровень сформированности правосознания и наличие опыта (жизненного и служебного) связаны с эффективностью служебной деятельности женщин-сотрудников ОВД, и данный фактор был назван «общий уровень сформированности правосознания в сочетании с жизненным и служебным опытом».

В третий фактор вошли показатели социометрических статусов женщинсотрудников (деловой, эмоциональный, интегральный). Определенное значение в данном факторе имеют показатели методики СМИЛ: 9-я шкала - 0,29; 5-я шкала - 0,23. При этом шкала 9 находится на противоположном полюсе относительно всех показателей данного фактора. Это говорит о взаимосвязи личностных особенностей женщин-сотрудников с их положением в коллективе в системе межличностных взаимодействий, что в целом и оказывает влияние на эффективность их служебной деятельности. Важно отметить, что социометрический статус личности в коллективе опосредован, с одной стороны, особенностями личности, с другой - характеристиками коллектива. Поэтому третий фактор называется «социометрический статус женщин-сотрудников в коллективе в системе межличностных взаимодействий, опосредованный их личностными особенностями и характеристиками коллектива».

Таким образом, анализ результатов исследования показал, что социально-психологическими факторами эффективности служебной деятельности женщин-сотрудников органов внутренних дел выступают: социально-психологические показатели служебных коллективов; общий уровень сформированности правосознания в сочетании с жизненным и служебным опытом; социометрический статус женщин в коллективе в системе межличностных взаимодействий, опосредованный их личностными особенностями и особенностями коллектива.

\section{Выводы}

Результаты проведенного исследования позволили сделать следующие выводы:

1. Социально-психологические факторы эффективности служебной деятельности женщин-сотрудников представлены на групповом 
и индивидуальном уровнях. Групповой уровень включает в себя социально-психологические показатели служебных коллективов; индивидуальный уровень - характеристики социометрических статусов и особенности личности женщин-сотрудников.

2. Социально-психологические показатели служебных коллективов органов внутренних дел, обусловленные количественным и гендерным составом, обнаруживают положительную (сплоченность и удовлетворенность) и отрицательную (напряженность и конфликтность) связи с эффективностью служебной деятельности женщин-сотрудников.

3. Установлена взаимосвязь эффективности служебной деятельности женщин-сотрудников органов внутренних дел с социометрическими показателями их деловых и эмоциональных статусов в служебном коллективе, опосредованных личностными особенностями женщин-сотрудников и особенностями самого коллектива.

4. Основная часть женщин-сотрудников, проходящих службу в органах внутренних дел, профессионально компетентны, эмоционально привлекательны, общительны и пользуются авторитетом в своих коллективах. Но при достаточно высоких оценках деловых и эмоциональных качеств женщин-сотрудников коллеги не стремятся выдвигать их на руководящие должности и не рассматривают в качестве потенциальных руководителей.

5. Уровень сформированности индивидуального правосознания, как одного из необходимых для сотрудников органов внутренних дел социальнопсихологических качеств личности, положительно связан с эффективностью служебной деятельности женщин-сотрудников ОВД.

6. Для женщин-сотрудников ОВД характерен стенический тип реагирования, преобладание возбудимых черт личности. Такие личностные особенности, как мягкость, сентиментальность, женственность, чувствительность, стремление быть опекаемой, найти опору, снижают эффективность служебной деятельности женщин-сотрудников.

7. Полученные результаты позволили выработать практические рекомендации по социально-психологическому сопровождению служебной деятельности женщин-сотрудников органов внутренних дел:

- в программу морально-психологической подготовки в раздел профессионально-психологической подготовки сотрудников органов внутренних дел включить тему: «Социально-психологические особенности женщин как субъектов профессиональной деятельности». Проведение занятия по данной теме позволит сотрудникам ОВД получить знания об особенностях женщин, профилактировать гендерные конфликты в служебных коллективах, повышать коммуникативную компетентность личного состава и повысить в целом уровень культуры общения в подразделениях ОВД; 
- рекомендуется включить в программы подготовки, переподготовки и повышения квалификации практических психологов ОВД учебные темы по следующим проблемам: «Гендерный аспект при профессиональном психологическом отборе на службу в ОВД», «Особенности социальнопсихологического сопровождения смешанных служебных коллективов ОВД», «Особенности психологической работы с женщинами-сотрудниками органов внутренних дел»;

- на основании результатов исследования предлагается разработать:

- для руководителей подразделений органов внутренних дел практические рекомендации по оптимизации социально-психологического климата в служебных коллективах с учетом гендерного состава;

- для практических психологов рекомендации на тему: «Гендерный аспект при профессиональном психологическом отборе на службу в органы внутренних дел»;

- у учитывая актуальную гендерную ситуацию в органах внутренних дел и выявленные закономерности, разработать программу социально-психологического сопровождения служебных коллективов с учетом их гендерного состава. В программу предлагается включить следующие разделы:

- лекционные занятия для руководителей подразделений ОВД на тему «Социально-психологические факторы эффективности служебной деятельности женщин-сотрудников органов внутренних дел» с целью получения знаний об особенностях женщин как субъектов служебной деятельности; повышения гендерной компетентности руководителей, профилактики гендерных конфликтов, повышения уровня культуры межличностного взаимодействия в ОВД;

- социально-психологические тренинги с целью оптимизации взаимоотношений в коллективе, повышения уровня коллективной работоспособности и профессиональной эффективности сотрудников, разработанные с учетом гендерного состава коллективов. Для смешанных коллективов, в которых примерное соотношение женщин и мужчин 20:80, рекомендовать социально-психологические тренинги с тематикой профессиональной деятельности («Психологические приемы в деятельности сотрудника ОВД», «Психологический портрет в работе юриста»). Для коллективов, в которых примерное соотношение женщин и мужчин 80:20, рекомендовать тренинги с социально-психологической тематикой («От коллектива к команде», «В коллективе дружба - легче служба»);

- социально-психологические тренинги на темы «Адаптационный тренинг для женщин», «Антистрессовый тренинг для женщин» с целью коррекции психоэмоциональных состояний женщин-сотрудников, обучения приемам самопомощи, саморегуляции. 


\section{Литература}

1. Андреева И. А., Корчмарюк И. А. Методика организации социально-психологических исследований в органах внутренних дел. Методическое пособие / Под общ. ред. канд. пед. наук В. Л. Кубышко. - М.: Изд-во ЦОКР МВД России, 2008. - 64 с.

2. Ануфриева Д. Ю. Профессиональное развитие женщин, работающих в органах внутренних дел // Психопедагогика в правоохранительных органах. Научно-практический журнал. - 2009. - № 4 (39). - С. 20-22.

3. Бендас Т. В. Гендерная психология: учебное пособие. - СПб.: Питер, 2008. - 431 c.

4. Демина М. А. Профессиональное воспитание женщин военнослужащих внутренних войск МВД России с учетом гендерных аспектов: дисс. ... канд. психол. наук. - СПб., 2005. - 197 с.

5. Иванова Т. А. Организационно-правовые проблемы работы с женщинами-сотрудниками органов внутренних дел (милиции) (на примере г. Москвы): дисс. ... канд. юрид. наук. - М., 2000. - 176 с.

6. Ильин Е. П. Дифференциальная психология профессиональной деятельности. - СПб.: Питер, 2011. - 432 с.

7. Комаров Е. И., Жукова В.Ф. Гендерный менеджмент. - М.: РИОР:ИНФРА-М, 2012. - 187 c.

8. Марьин М. И., Котенев И. О., Киселева Л. Е. Методика экспертных оценок эффективности адаптации к управленческой деятельности выпускников Академии управления МВД России. - М.: Изд-во Академии управления МВД России, 2012. - 96 с.

9. Марьин М. И., Ловчан С. И., Иванихина И. В. и др. Оценка и оптимизация психологического климата, стиля руководства в органах управления и подразделениях Государственной противопожарной службы. Методическое пособие / Под. ред. Е. А. Мешалкина. - 2-е изд. - М.: Изд-во ВНИИПО, 1998. - С. 5.

10. Марьин М. И., Петров В. Е., Адаев А. И., Бореко А. В. Социально-психологическая компетентность руководителя органа внутренних дел. Учебнометодическое пособие. - М.: Изд-во ЦОКР МВД России, 2005. - 212 с.

11. Обозов Н. Н. Женщина + мужчина = ?! - СПб.: ЛНПП «Облик», 2007. - 74 с.

12. Овчинникова В. В. Влияние гендерных установок на взаимоотношения в разнополых воинских коллективах (на примере вузов ФСБ России пограничного профиля): автореф. дисс. ... канд. психол. наук. - Голицино, 2006. - 21 с.

13. Основные виды деятельности и психологическая пригодность к службе в системе органов внутренних дел: справочное пособие / Под ред. Б. Г. Бовина, Н. И. Мягких, А. Д. Сафронова. - М., 1997. - 344 с. 
14. Папкин А. И. Совершенствование социально-психологического климата в подразделениях и службах ОВД: методические рекомендации. - Домодедово: Изд-во РИПК работников МВД России, 1998. - 27 с.

15. Психологическое изучение личности сотрудника органов внутренних дел при аттестации: учебно-методическое пособие. - М.: Изд-во ЦОКР МВД России, 2007. - 216 с.

16. Психология управления: учебник / Под ред. В. И. Черненилова. - М.: Изд-во Академии управления МВД России, 2011. - 352 с.

17. Сведения о состоянии работы с кадрами органов внутренних дел Российской Федерации за 2015 год. - М., 2016. - 74 с.

18. Сидоренко Е. В. Методы математической обработки в психологии. - СПб.: Речь, 2001. - 350 с.

19. Смирнов А. И. Женщина на военной службе: новые возможности и социальные права. - М.: Центр общечеловеческих ценностей, 2000. - 144 с.

20. Собчик Л. Н. Введение в психологию индивидуальности. - М.: Изд-во Института прикладной психологии, 1998. - 512 с.

21. Социальная психология: учебник для студентов вузов / Под ред. А. М. Столяренко. - 2-е изд., доп. - М.: ЮНИТИ-ДАНА, 2009. - 511 с.

22. Социально-психологический климат в служебных коллективах: методическое пособие / Под общей ред. М. И. Марьина, А. Е. Мешалкина. - М.: Изд-во ЦОКП МВД России, 2001. - С. 8-9.

23. Энциклопедия юридической психологии / Под. общ. ред. проф. А. М. Столяренко. - М.: ЮНИТИ-ДАНА, Закон и право, 2003. - С. 475.

24. Ясюкова Л. А. Правосознание: диагностика и закономерности развития // Прикладная психология. - 2000. - № 4. - С. 1-13.

25. Ясюкова Л. А., Самойлова В. А. Состояние и тенденции развития правосознания в современном российском обществе // Человек и общество. Научный и общественный альманах. - 2005. - № 31. - С. 60-84.

26. Mayo E. The Human Problems of an Industrial Civilization (Early Sociology of Management \& Organizations) Hardcover. - New York: Routledge Publ.; Reprint edition, 2003. - 208 p. 